\title{
Effect of operating conditions on the performances of multichannel ceramic UF membranes for textile mercerization wastewater treatment
}

\section{Maja Zebić Avdičević, Krešimir Košutić \& Slaven Dobrović}

To cite this article: Maja Zebić Avdičević, Krešimir Košutić \& Slaven Dobrović (2017) Effect of operating conditions on the performances of multichannel ceramic UF membranes for textile mercerization wastewater treatment, Environmental Technology, 38:1, 65-77, DOI: 10.1080/09593330.2016.1186225

To link to this article: http://dx.doi.org/10.1080/09593330.2016.1186225

$$
\text { 曲 Published online: } 26 \text { May } 2016 .
$$

Submit your article to this journal

山 Article views: 89

Q View related articles $\square$

View Crossmark data $\nearrow$ 


\title{
Effect of operating conditions on the performances of multichannel ceramic UF membranes for textile mercerization wastewater treatment
}

\author{
Maja Zebić Avdičevića ${ }^{a}$ Krešimir Košutićb and Slaven Dobrovića \\ ${ }^{\mathrm{a}}$ Faculty of Mechanical Engineering and Naval Architecture, Department of Energy, Power Engineering and Environment, Chair of Water and \\ Environmental Engineering, University of Zagreb, Zagreb, Croatia; ${ }^{b}$ Faculty of Chemical Engineering and Technology, Department of Physical \\ Chemistry, University of Zagreb, Zagreb, Croatia
}

ABSTRACT

Textile wastewaters are rated as one of the most polluting in all industrial sectors, and membrane separation is the most promising technology for their treatment and reuse of auxiliary chemicals. This study evaluates the performance of three types of tubular ceramic ultrafiltration membranes differing by mean pore size $(1,2$ and $500 \mathrm{kDa})$ treating textile mercerization wastewater from a textile mill at different operating conditions: cross-flow velocity (CFV) and temperature. Acceptable results were obtained with $1 \mathrm{kDa}$ ceramic membrane, with rejection efficiencies $92 \%$ for suspended solids, $98 \%$ for turbidity, $98 \%$ for color and $53 \%$ for total organic carbon at $20^{\circ} \mathrm{C}$ and $3 \mathrm{~m} \mathrm{~s}^{-1}$ CFV. Highest fouling effect was observed for $500 \mathrm{kDa}$ membrane and lowest CFV. According to the observed results, $1 \mathrm{kDa}$ membrane could be used for the treatment of wastewater from the textile mercerization process in terms of permeate quality.
ARTICLE HISTORY

Received 29 July 2015

Accepted 29 April 2016

\section{KEYWORDS}

Ultrafiltration; ceramic membrane; textile industry; mercerization wastewater; flux decline

\section{Introduction}

Textile wastewater is considered as one of the most polluted in all industrial sectors.[1] Reuse of the chemicals and water from industrial processes due to more stringent regulations and to improve the resource efficiency of today's society has become very important.[2-7]

Textile industry processes consist of several stages: mercerization, bleaching and dyeing. These activities use from 5 to 40 times higher quantities of water than fiber weight and consequently generate large volumes of wastewater.[7] Mercerization is the first stage of textile treatment, which includes the treatment of textile with highly caustic alkaline solution of sodium hydroxide and auxiliary chemicals. Mercerization process improves textile fiber strength and dye efficiency by rearranging the cellulose molecules in the fibers.[8] First, the cotton is immersed in $25 \%$ sodium hydroxide and $3-4 \%$ of wetting agent solution (anionic and nonionic surfactants) for textile during a certain period of time, and then it is washed with hot and cold water before final drying. After washing cotton, highly alkaline wastewater effluents occur which contain sodium hydroxide, surfactants and suspended solids. Alkaline solutions and surfactants can be used again in the mercerization process if suspended solids are removed using ultrafiltration (UF) process as the appropriate treatment method.[9]
Membrane technologies have been widely recognized as an adequate option for wastewater treatment and reclamation because it can selectively remove contaminants from wastewater.[3,6,10-12] Today, polymeric membranes are the most commercially used,[1] but ceramic membranes have higher thermal, chemical and mechanical stability compared to polymeric membranes. $[1,6,11,13-15]$ Since wastewater from the mercerization process has high temperature and it is extremely alkaline, ceramic membranes could be the appropriate choice for its treatment. Ceramic membranes also show extended lifetime than polymeric membranes, but are considered more expensive,[16] although their cost has been continuously reduced over the last years.[1] The main drawback of the ceramic membranes is the membrane fouling by organic, inorganic or biological material that causes a decrease in membrane performance and operational costs due to energy consumption and maintenance.[2,13,14] The fouling phenomenon is very complex, hard to predict and depends on feed water quality and interaction between the membrane material and retained matter.[11] Nevertheless, in the literature there are not many papers that involve the treatment of mercerization wastewater with ceramic membranes.

The aim of this study is the application of ceramic membranes for the treatment of mercerization wastewater in terms of the permeate quality. The effect of the 
operating conditions such as temperature and cross-flow velocity (CFV) on membrane fouling and normalized flux decline for three ceramic membranes of different molecular weight cut-off (MWCO) was investigated. Overall evaluation of the performance of tubular ceramic membranes for mercerization wastewater treatment will also include detailed monitoring of reached permeate quality.

\section{Materials and methods}

\subsection{Characteristics of wastewater}

The textile wastewater samples for the experiments in this work were supplied by a textile industry from Zagreb (Unitas Co.), Croatia, where mercerizing, dyeing and finishing activities were conducted. During the mercerization process, textile was immersed in $25 \%$ sodium hydroxide solution and $1-2 \%$ of wetting agent. After mercerization, textile was rinsed with hot water and cold rinse water of $80^{\circ} \mathrm{C}$ and $18-20^{\circ} \mathrm{C}$, respectively. The wastewater from washing after the mercerizing process was collected and used for UF treatment. Process performance was evaluated by the determination of the effect of the following parameters: $\mathrm{pH}$, alkalinity, conductivity, total suspended solids (TSS), total dissolved solids (TDS), turbidity, total organic carbon (TOC) and color. The characteristics of mercerization wastewater used in this study are presented in Table 2.

Experiments were conducted with raw mercerization wastewater samples without any correction or addition, which contained approximately $1.4 \%$ of sodium hydroxide, high concentration of TSS $\left(100 \mathrm{mg} \mathrm{L}^{-1}\right)$ and TOC (499.2 $\left.\mathrm{mg} \mathrm{L}^{-1}\right)$. Cellulose fibers and surfactants from the wetting agent are considered to be the main source of suspended solids and organic components.

Chemical cleaning of membranes was done with technical grade $\mathrm{NaOH}, \mathrm{HNO}_{3}, \mathrm{NaOCl}$ and analytical grade $\mathrm{H}_{2} \mathrm{O}_{2}$ (Kemika, Zagreb).

\subsection{Analytical methods}

Alkalinity was determined according to Standard Methods $2320 \mathrm{~B}$ titration method. Conductivity measurements were made by a Knick Portamess conductometer and $\mathrm{pH}$ values were determined using a $\mathrm{pH}$-meter (Mettler Toledo). Concentration of dissolved organic compounds was measured using a TOC analyzer (SHIMADZU TOC- $\mathrm{V}_{\mathrm{CPH}}$ ) using the non-purgeable organic carbon method. TDS and TSS values were determined gravimetrically according to the Standard Methods $2540 \mathrm{C}$ and $2540 \mathrm{D}$, respectively. Turbidity was measured using a HACH turbidimeter 2100 AN. Temperature was determined using a Pt-100 temperature transducer (MA
Table 1. Ceramic membrane characteristics.

\begin{tabular}{|c|c|c|c|}
\hline & $\begin{array}{l}500 \mathrm{kDa} \\
\text { membrane }\end{array}$ & $\begin{array}{c}2 \mathrm{kDa} \\
\text { membrane }\end{array}$ & $\begin{array}{c}1 \mathrm{kDa} \\
\text { membrane }\end{array}$ \\
\hline Manufacturer & \multirow{2}{*}{\multicolumn{3}{|c|}{$\begin{array}{l}\text { Likuid Nanotek } \\
\text { Tubular multichannel }\end{array}$}} \\
\hline Type & & & \\
\hline Active layer & $\begin{array}{c}\mathrm{Al}_{2} \mathrm{O}_{3}, \mathrm{TiO}_{2} \\
\mathrm{ZrO}_{2}\end{array}$ & $\mathrm{ZrO}_{2}$ & $\mathrm{ZrO}_{2}$ \\
\hline Support layer & & $\mathrm{Al}_{2} \mathrm{O}_{3}$ & \\
\hline MWCO & 500 kDa & $2 \mathrm{kDa}$ & $1 \mathrm{kDa}$ \\
\hline Number of channels & & 19 & \\
\hline External diameter $(\mathrm{mm})$ & & 25 & \\
\hline Channel diameter (mm) & & 3.5 & \\
\hline Length (mm) & & 200 & \\
\hline Range of $\mathrm{pH}$ resistance & & $0-14$ & \\
\hline Operating pressure (bar) & & $0-10$ & \\
\hline Thermal stability $\left({ }^{\circ} \mathrm{C}\right)$ & & $<300$ & \\
\hline $\begin{array}{l}\text { Effective filtration area } \\
\left(\mathrm{m}^{2}\right)\end{array}$ & & 0.0418 & \\
\hline $\begin{array}{l}\text { Pure water permeability } \\
\left(\mathrm{L} \mathrm{m}^{-2} \mathrm{~h}^{-1} \text { bar }^{-1}\right)\end{array}$ & 432 & 76 & 42 \\
\hline
\end{tabular}

TERM MWT 410) and a laboratory Pt-100 sensor. Color was measured using HACH DR4000U spectrophotometer according to the ASTM D1209 method.

\subsection{Membrane modules}

UF experiments were conducted using three commercially available UF ceramic membrane modules supplied from LIKUID (Likuid Nanotek S.L., Spain) characterized by different MWCO: 500, 2 and $1 \mathrm{kDa}$. The $500 \mathrm{kDa}$ membrane is composite multichannel type with a titanium oxide, alumina oxide and zirconium oxide active layer, and an alumina oxide supporting layer. 2 and $1 \mathrm{kDa}$ membranes are multichannel type with a zirconium oxide active layer and an alumina oxide supporting layer. All membrane modules have dimensions of 200 $\mathrm{mm}$ length, external diameter of $25 \mathrm{~mm}$ and channel diameter of $3.5 \mathrm{~mm}$. The membrane modules are composed of 19 inside-out channels with a total membrane surface of $0.0418 \mathrm{~m}^{2}$ and placed in a stainless steel housing. Technical characteristics of the membranes used in the study are summarized in Table 1.

Membrane permeability to pure water was measured experimentally at $20^{\circ} \mathrm{C}$ for each membrane module using deionized water (DW) at the CFV of $3 \mathrm{~m} \mathrm{~s}^{-1}$. Membrane permeability was obtained following Darcy's law:

$$
J_{W}=L_{W} \cdot T M P,
$$

where $L_{w}$ represents the permeability of the membrane.

\subsection{UF membrane unit}

UF experiments were performed in a laboratory set-up shown in Figure 1. It is a cross-flow membrane system consisting of two tanks containing the feed and cleaning solutions, a centrifugal pump (WILO WJ-202-x-EM/B), to 
Table 2. Characteristic of raw mercerization wastewater and permeate of ceramic UF membranes at $20^{\circ} \mathrm{C}$ and $50^{\circ} \mathrm{C}$.

\begin{tabular}{|c|c|c|c|c|c|c|c|}
\hline \multirow[b]{2}{*}{ Parameter } & \multirow[b]{2}{*}{ Mercerization wastewater } & \multicolumn{4}{|c|}{$20^{\circ} \mathrm{C}$} & \multicolumn{2}{|c|}{$50^{\circ} \mathrm{C}$} \\
\hline & & $500 \mathrm{kDa}$ & $2 \mathrm{kDa}$ & $1 \mathrm{kDa}$ & $1 \mathrm{kDa}^{\mathrm{a}}$ & $500 \mathrm{kDa}$ & $1 \mathrm{kDa}$ \\
\hline $\mathrm{pH}$ & 13.30 & 13.13 & 13.04 & 13.23 & 13.06 & 13.14 & 13.10 \\
\hline Alkalinity as $\mathrm{CaCO}_{3}\left(\mathrm{mg} \mathrm{L}^{-1}\right)$ & 20,000 & 12,000 & 11,500 & 11,000 & 10,000 & 14,500 & 12,000 \\
\hline Conductivity $\left(\mu \mathrm{S} \mathrm{cm}^{-1}\right)$ & 75,100 & 48,400 & 48,700 & 43,900 & 44,100 & 51,700 & 44,200 \\
\hline TSS $\left(\mathrm{mg} \mathrm{L}^{-1}\right)$ & 100.0 & 45.6 & 29.0 & 8.9 & 7.8 & 47.0 & 11.67 \\
\hline TDS $\left(\mathrm{mg} \mathrm{L}^{-1}\right)$ & 20,957 & 18,523 & 14,340 & 14,140 & - & 15,210 & 12,930 \\
\hline Turbidity (NTU) & 14.60 & 2.57 & 0.27 & 0.28 & 0.27 & 3.26 & 0.43 \\
\hline TOC $\left(\mathrm{mg} \mathrm{L}^{-1}\right)$ & 499.20 & 398.47 & 238.85 & 282.22 & 262.90 & 315.08 & 239.71 \\
\hline Color $(\mathrm{Pt}-\mathrm{Co})$ & 205 & 81 & 52 & 4 & - & 80 & 4 \\
\hline
\end{tabular}

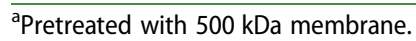

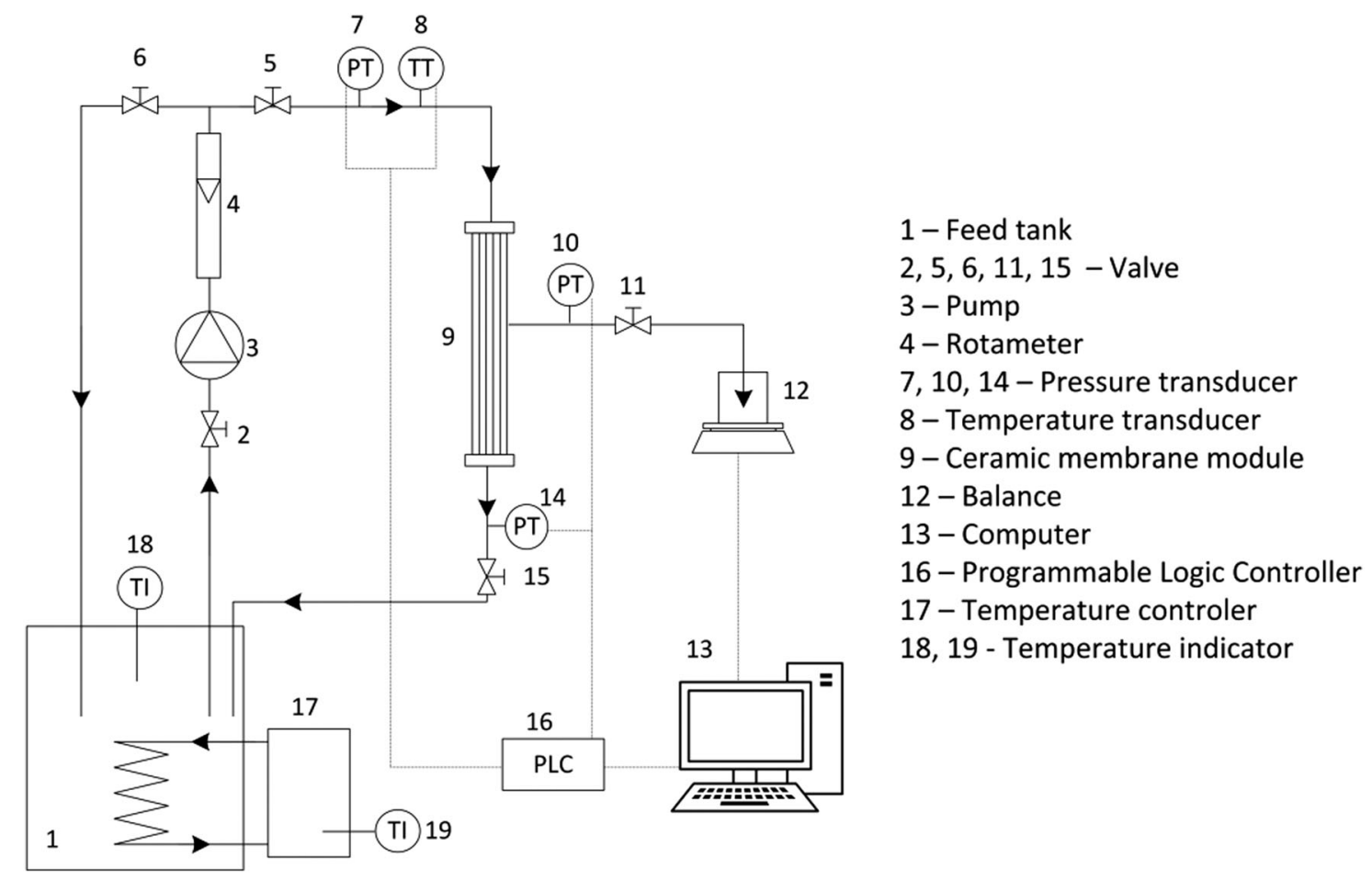

Figure 1. Schematic representation of the ceramic membrane separation unit.

circulate continuously the feed solution through the system, and LIKUID ceramic membrane modules. Feed solution flow rate was controlled by the regulation of the inlet flow rate with a rotameter. The unit was equipped with a pressure (Danfoss MB 3000; 060G3857; 0-6 bar) and a Pt-100 temperature transducer (MA TERM MWT 410) that were connected to the Programmable Logic Controller (Allan Bradley MicroLogix 1400). Three pressure sensors were used to measure the feed stream pressure $p_{\mathrm{F}}$, the outlet (retentate) stream pressure $p_{R}$ and the permeate pressure $p_{\mathrm{P}}$. The transmembrane pressure (TMP) was calculated based on the measured values of the given pressures by the relation:

$$
\mathrm{TMP}=\frac{p_{\mathrm{F}}+p_{\mathrm{R}}}{2}-p_{\mathrm{P}}
$$

and it was adjusted using the valve at the retentate outlet. Pressure and temperature data were collected every $5 \mathrm{~s}$ using data acquisition software. Permeate flow rate was determined gravimetrically using an analytical balance (Mettler PM 6000) and cumulative mass of permeate was recorded in a computer every $5 \mathrm{~s}$ via RS-232 connection. Water permeate flux was calculated using the following equation:

$$
J_{W}=\frac{V_{P}}{A \cdot t^{\prime}}
$$

where $J_{W}\left(\mathrm{~L} \mathrm{~m}^{-2} \mathrm{~h}^{-1}\right)$ is the permeate flux, $V_{\mathrm{P}}\left(\mathrm{L} \mathrm{h}^{-1}\right)$ is the volume flow, $A\left(\mathrm{~m}^{2}\right)$ is the active membrane surface and $t(h)$ is the filtration time. Volume flow was calculated based on the value of mass for a given time and after the density correction had been made. 


\subsection{Experimental procedures}

Effluents from the textile factory were first pre-filtered through cartridge filters $(10 \mu \mathrm{m})$ to remove the larger particles and suspended solids from the mercerization wastewater to avoid membrane fouling and module damage. Pre-filtered wastewater was filled into the 125 $\mathrm{L}$ feed tank, and treated using three ceramic membrane modules with different MWCO: 1, 2 and 500 kDa. Separation experiments were conducted in the cross-flow separation mode with complete retentate recycling and continuous removal of the permeate stream. Experiments were conducted for two initial permeate fluxes and at two different temperatures $\left(20 \pm 1^{\circ} \mathrm{C}\right.$ and $50 \pm 1^{\circ}$ C). The CFV for $500 \mathrm{kDa}$ membrane was $1,2,3$ and 4 $\mathrm{m} \mathrm{s}^{-1}$, for $2 \mathrm{kDa}$ membrane $3 \mathrm{~m} \mathrm{~s}^{-1}$ and for $1 \mathrm{kDa}$ membrane 1,2 and $3 \mathrm{~m} \mathrm{~s}^{-1}$ by adjusting the inlet stream flow rate. Mercerization wastewater was heated to $50^{\circ} \mathrm{C}$, simulating the real conditions of the raw wastewater at the textile factory. Temperature of the feed mercerization wastewater was adjusted with a spiral heat exchanger which was regulated with a thermostatic bath (Lambda) and controlled by Pt-100 sensors. The temperature was kept constant during the experiments.

Each experiment commenced by the determination of the pure permeability to DW measuring water permeate flux $\left(J_{W}\right)$ at different TMPs for adequate CFV and temperature.

Mercerization wastewater normalized flux $\left(J_{\mathrm{P}}\right)$ was determined by measuring permeate flux $\left(J_{W}\right)$ at different TMPs for adequate CFV and temperature. Subsequent to each performed separation test, membranes were rinsed with DW to determine the flux recovery. Rinsing process with DW was not sufficient to reach the initial normalized flux and only the reversible fouling was removed. To achieve a complete recovery of the normalized flux, a severe chemical cleaning in place (CIP) was conducted. The membrane was subjected to alkaline cleaning using $1 \% \mathrm{NaOH}$ solution by circulating it through the system with the permeate valve off for $30 \mathrm{~min}$. The membrane was washed with DW and then cleaned with $0.05 \% \mathrm{NaOCl}$ solution during $30 \mathrm{~min}$ by recirculating through the system in the regular direction with the permeate valve on/off. The membrane was soaked in $\mathrm{NaOCl}$ solution for $1 \mathrm{~h}$ and then rinsed with DW until neutrality. Permeate normalized flux was measured and compared to the initial value. If necessary, the membrane was cleaned again until the nearly initial normalized flux was restored for the next experiment. In some cases after cleaning with $\mathrm{NaOCl}$ solution, $1 \% \mathrm{H}_{2} \mathrm{O}_{2}$ solution was used. Every CIP step was conducted at temperature of $50-60^{\circ} \mathrm{C}$ and at tangential velocity of $3 \mathrm{~m} \mathrm{~s}^{-1}$. Satis- factory flux recovery results were accomplished only when $\mathrm{NaOCl}$ solution was used.

Separation experiments using mercerization wastewater were carried out for $30 \mathrm{~min}$ for each run and permeate samples were collected from feed and permeate streams for later characterization. For the collected samples $\mathrm{pH}$, conductivity, TSS, TDS, TOC, turbidity, color and alkalinity were analyzed.

\subsection{Energy consumption}

Energy consumption in tangential UF involves the energy required for retentate recirculation and for permeate flow. According to Equation (4), the calculation result is expressed by the total energy consumption $\left(E_{\mathrm{TF}}\right)$ in kWh per cubic meter of produced permeate:

$$
E_{\mathrm{TF}}=\frac{Q_{\mathrm{CF}} \cdot \Delta p_{\mathrm{F}}}{\eta_{\mathrm{F}} \cdot Q_{\mathrm{P}} \cdot 3600}+\frac{Q_{\mathrm{P}} \cdot \mathrm{TMP}}{\eta_{\mathrm{F}} \cdot Q_{\mathrm{P}} \cdot 3600}
$$

where $Q_{C F}$ and $Q_{p}$ are the feeding and the permeate flow rate $\left(\mathrm{m}^{3} \mathrm{~s}^{-1}\right), \eta_{\mathrm{F}}$ is the feed pump yield, $\Delta p_{\mathrm{F}}(\mathrm{Pa})$ is the pressure drop through membrane and TMP $(\mathrm{Pa})$ is the transmembrane pressure. For the calculation carried out in this study, the pump yield is equal to 0.75 . Calculated energy consumption corresponds to the energy consumption of the feed pump.

\section{Results and discussion}

\subsection{Membrane characterization}

The water flux increases with increasing TMP, and the slope of the straight line obtained by plotting the pure water flux versus TMP corresponds to initial pure water membrane permeability $\left(L_{w}\right)$ according to Darcy's law (Equation (3)).

Normalized flux is an important factor to be considered during the UF process. Prior to the separation experiments of the mercerization wastewater, membrane permeability to DW was determined by recording the permeate flux versus TMP diagram using 1, 2 and $500 \mathrm{kDa}$ ceramic membranes and plotting as shown in Figure 2. As it was expected, the given results fit well with Darcy's law, and the slope corresponds to the permeability. For mercerization wastewater, water fluxes as a function of applied pressure are represented in Figure 2. As a result of higher total resistance and viscosity of the mercerization wastewater, the pure water flux was higher compared to that of mercerization wastewater when the same membrane was used,[8] and it was $41.9 \mathrm{~L} \mathrm{~m}^{-2} \mathrm{~h}^{-1}$ $\operatorname{bar}^{-1}\left(R^{2}=0.9927\right)$ for DW and $19.7 \mathrm{~L} \mathrm{~m}^{-2} \mathrm{~h}^{-1} \mathrm{bar}^{-1}$ $\left(R^{2}=0.9873\right)$ for mercerization wastewater for $1 \mathrm{kDa}$ 


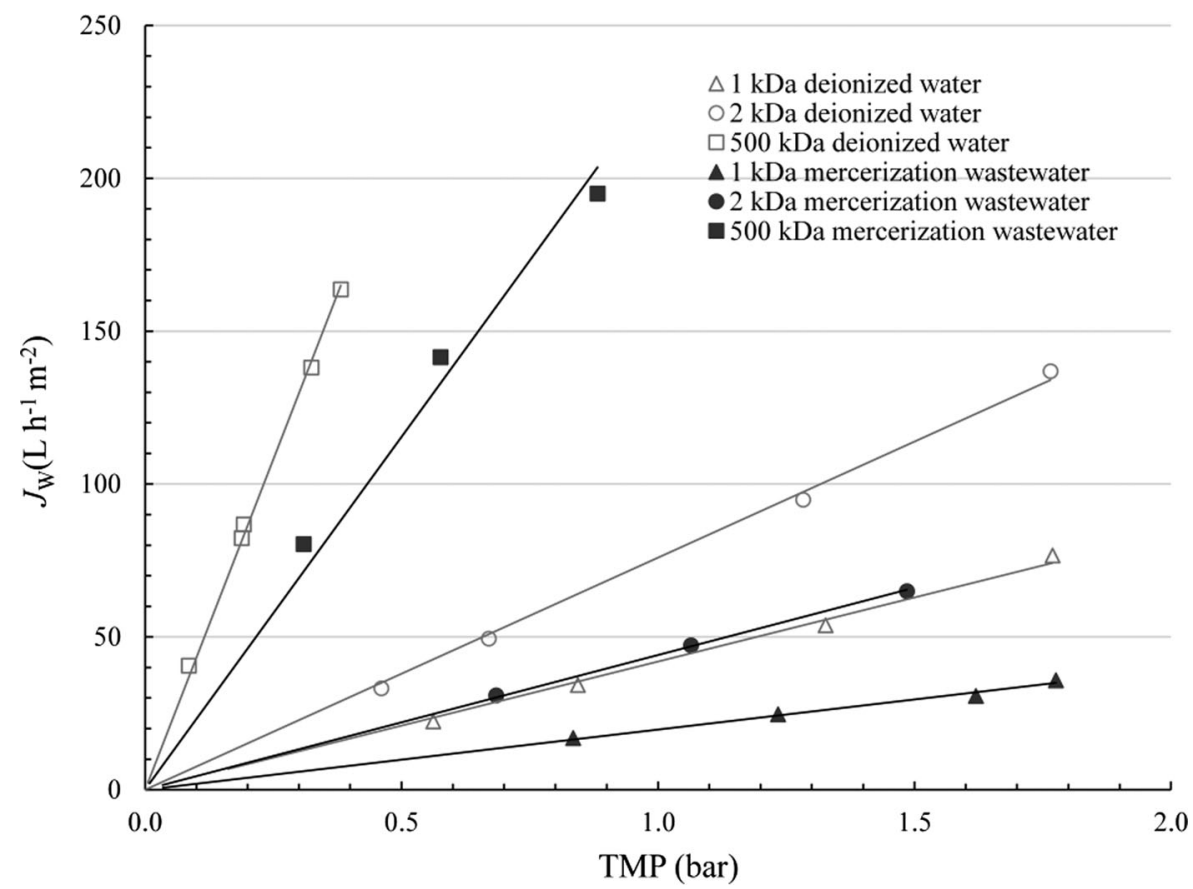

Figure 2. Dependence of the permeate fluxes $\left(J_{W}\right)$ for DW and mercerization wastewater on $\operatorname{TMP}\left(T=20^{\circ} \mathrm{C}, \mathrm{CFV}=3 \mathrm{~m} \mathrm{~s}^{-1}\right)$.

membrane; $75.9 \mathrm{~L} \mathrm{~m}^{-2} \mathrm{~h}^{-1} \mathrm{bar}^{-1}\left(R^{2}=0.9969\right)$ for DW and $44.1 \mathrm{~L} \mathrm{~m}^{-2} \mathrm{~h}^{-1} \mathrm{bar}^{-1}\left(R^{2}=0.9984\right)$ for mercerization wastewater for $2 \mathrm{kDa}$ membrane and $432.39 \mathrm{~L}$ $\mathrm{m}^{-2} \mathrm{~h}^{-1} \mathrm{bar}^{-1}\left(R^{2}=0.9966\right)$ for DW and $230.8 \mathrm{~L} \mathrm{~m}^{-2}$ $\mathrm{h}^{-1} \operatorname{bar}^{-1}\left(R^{2}=0.9651\right)$ for mercerization wastewater when $500 \mathrm{kDa}$ membrane was used.

\subsection{Effect of the MWCO}

Figure 3 represents the UF test sample for $500 \mathrm{kDa}$ membrane. Figure 4 illustrates the evolution of normalized flux $\left(J_{\mathrm{P}} / J_{\mathrm{PO}}\right)$ at the CFV of $3 \mathrm{~m} \mathrm{~s}^{-1}$ and temperature $20^{\circ} \mathrm{C}$ during $30 \mathrm{~min}$ of mercerization wastewater UF with tested ceramic membranes. It is observed that the normalized fluxes slightly decline for all three tested membranes after $30 \mathrm{~min}$. Approximately, an equally small normalized flux decrease was observed for 1 and $2 \mathrm{kDa}$ membranes, while $500 \mathrm{kDa}$ membrane showed a higher flux decline. This low membrane fouling phenomenon for 1 and $2 \mathrm{kDa}$ membranes was probably the result of a favorable relationship between CFV, pore size and rejected matter. As reported,[17] particles rejected by small pore size membranes could roll off under the forces generated by cross-flow, therefore, not causing membrane blockage. In the case of 500 $\mathrm{kDa}$ membrane, flux decline is most probably the result of particles migration through the pores, subsequent adsorption causing enhanced pore blockage or plugging.[1,10]
Comparison of permeates quality for each ceramic membrane for the most important parameters is given in Table 2. As it was expected, the highest TSS and turbidity removal was achieved with $1 \mathrm{kDa}$ membrane and it was $91.1 \%$ and $98.15 \%$, respectively. TOC removal was $53.90 \%$ and alkalinity was the lowest for $1 \mathrm{kDa}$ membrane permeate. From the literature, it is known that cellulose is soluble in concentrated strong alkali solutions, such as sodium hydroxide, at low temperatures. The aqueous alkali systems do not completely disrupt the crystalline structure of the cellulose and the solubility is limited to cellulose with low degree of polymerization. [18] It is assumed that the remaining organic compounds in the $1 \mathrm{kDa}$ permeate refer to surfactants from the wetting agent and dissolved cellulose molecules. According to the expectations, $\mathrm{pH}$ value, TDS and conductivity levels were approximately the same for 1 and $2 \mathrm{kDa}$ membrane permeate because the membrane pores are too large to maintain the reflected dissolved constituents such as sodium hydroxide and surfactants.

According to the results given in Table 1 , it was decided to continue research not only with 500 and 1 $\mathrm{kDa}$ as separate membranes, but also with both membranes in the series mode.

\subsection{Effect of operating conditions}

In order to select an adequate membrane for the mercerization wastewater treatment, membrane performance was investigated for 500 and $1 \mathrm{kDa}$ membranes at 


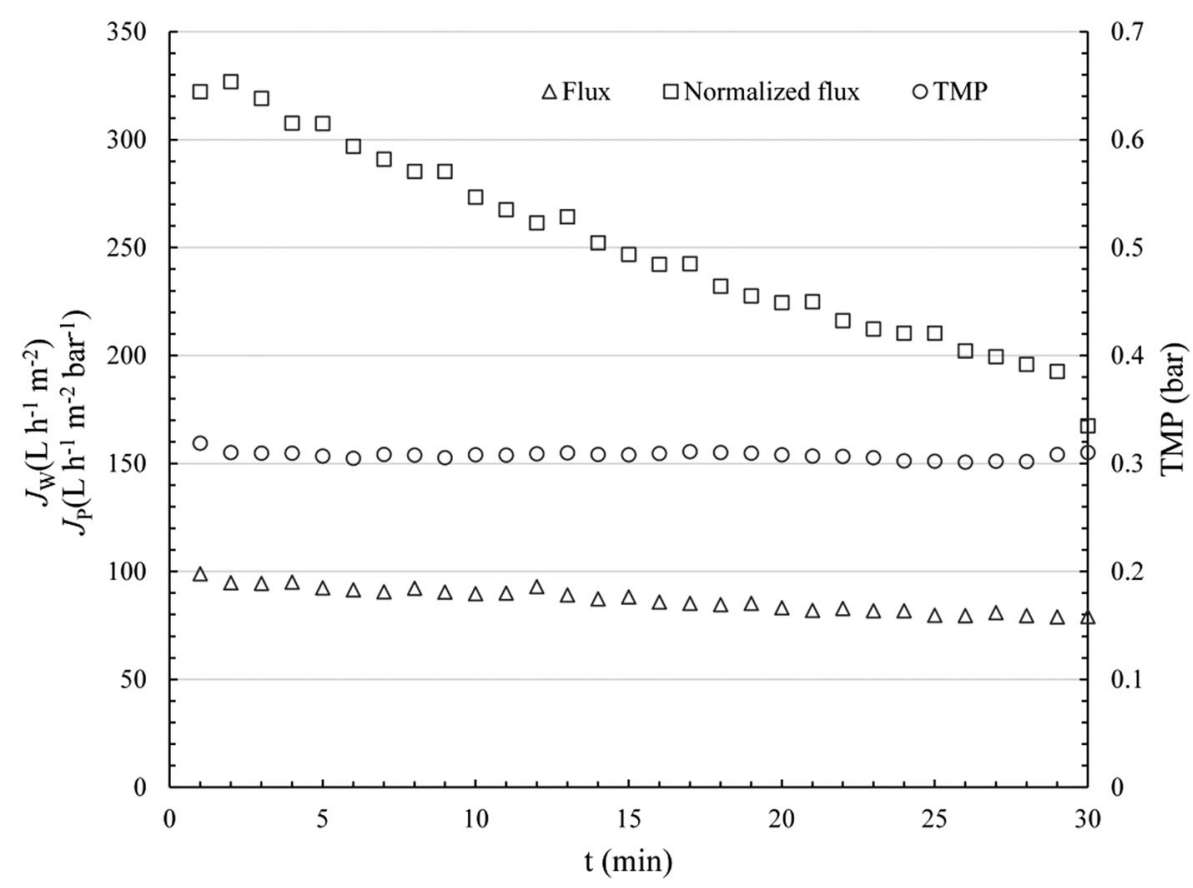

Figure 3. UF test example for $500 \mathrm{kDa}$ membrane: evolution of the permeate flux $\left(\mathrm{J}_{\mathrm{W}}\right)$, the normalized permeate flux $\left(J_{\mathrm{P}}\right)$ and TMP at $T=50^{\circ} \mathrm{C}$ and $4 \mathrm{~m} \mathrm{~s}^{-1} \mathrm{CFV}$.

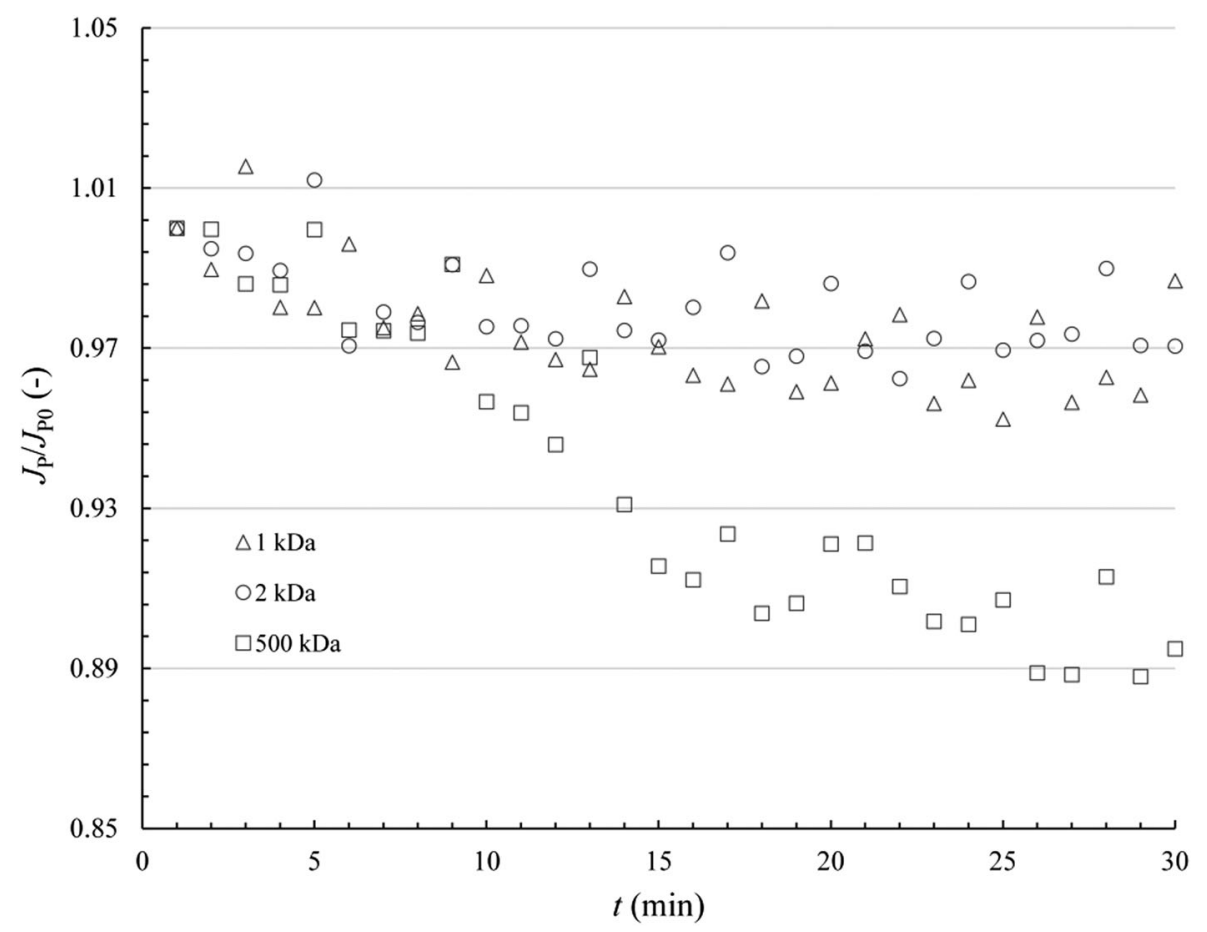

Figure 4. Evolution of the normalized permeate flux $\left(J_{\mathrm{P}} / J_{\mathrm{P} 0}\right)$ of mercerization wastewater for tested ceramic membranes $\left(T=20^{\circ} \mathrm{C}\right.$, $\mathrm{CFV}=3 \mathrm{~m} \mathrm{~s}^{-1}$ ).

different CFVs. The influence of high and low initial permeate flux on membrane performance through the change in normalized flux at different CFVs for 500 and $1 \mathrm{kDa}$ ceramic membranes was determined. For 500
$\mathrm{kDa}$ membrane, the initial permeate flux was $100 \mathrm{~L}$ $\mathrm{m}^{-2} \mathrm{~h}^{-1}$ at TMP $0.41 \mathrm{bar}$, temperature $20^{\circ} \mathrm{C}$ and CFVs: $1,2,3$ and $4 \mathrm{~m} \mathrm{~s}^{-1}$. Figure 5 illustrates the normalized flux as the function of time for 500 and $1 \mathrm{kDa}$ 


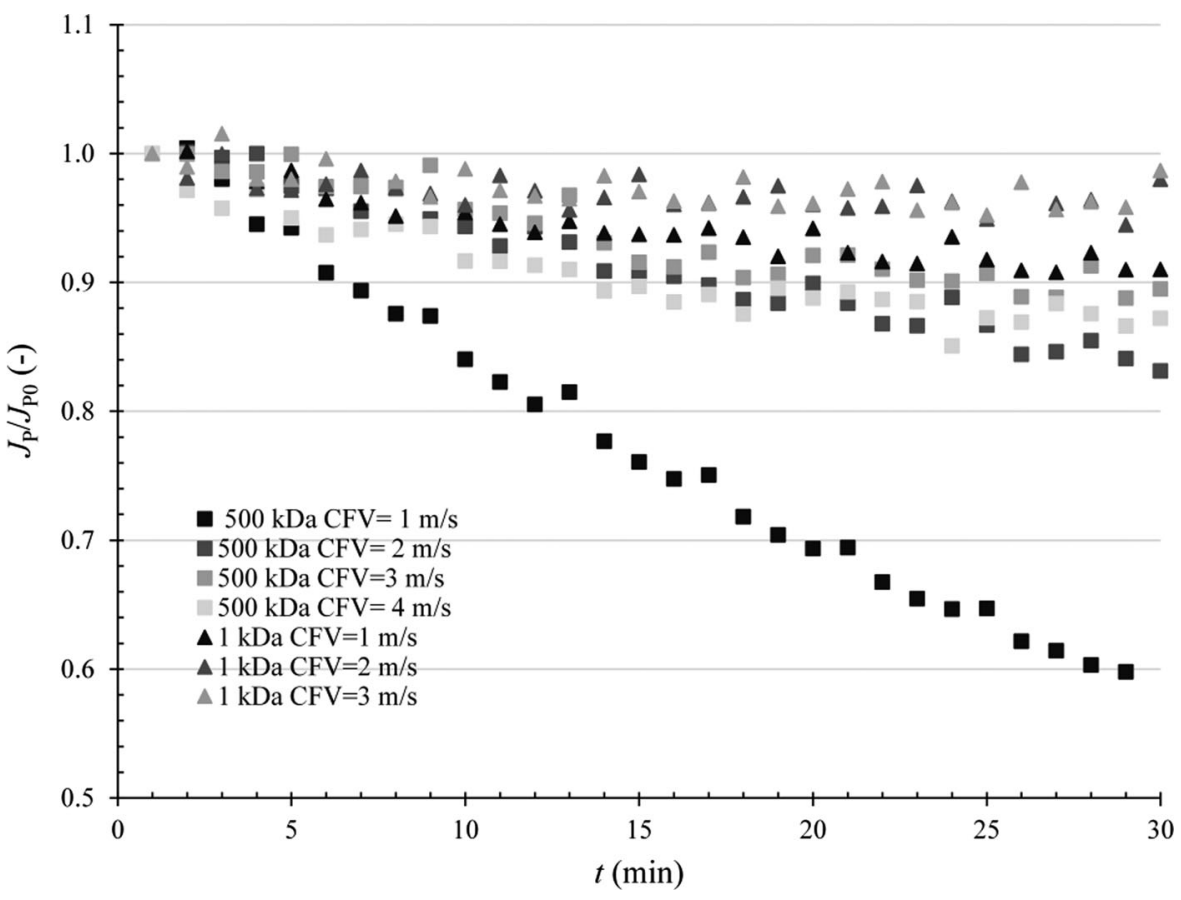

Figure 5. Effect of CFV on normalized permeate flux $\left(J_{\mathrm{P}} / J_{\mathrm{PO}}\right)$ for 500 and $1 \mathrm{kDa}$ ceramic membranes at initial fluxes of $100 \mathrm{~L} \mathrm{~m} \mathrm{~h}^{-1} \mathrm{and}^{-1}$ $30 \mathrm{~L} \mathrm{~m}^{-2} \mathrm{~h}^{-1}$, respectively.

membranes during the 30 min of experiments for higher initial fluxes. The highest decrement of normalized flux from 1 to 0.59 was recorded for $500 \mathrm{kDa}$ membrane at CFV $1 \mathrm{~m} \mathrm{~s}^{-1}$.

Experiments with $1 \mathrm{kDa}$ membrane were also conducted for $30 \mathrm{~min}$, at TMP $1.8 \mathrm{bar}$ and temperature $20^{\circ}$ C. The initial permeate flux was $30 \mathrm{~L} \mathrm{~m}^{-2} \mathrm{~h}^{-1}$, and the tested CFVs were 1,2 and $3 \mathrm{~m} \mathrm{~s}^{-1}$. The experiment at CFV $4 \mathrm{~m} \mathrm{~s}^{-1}$ could not be conducted because of too high pressure drop in the recirculation loop. The highest decrement of normalized flux was recorded for CFV $1 \mathrm{~m} \mathrm{~s}^{-1}$. For both membranes, intensification of cross-flow resulted in a decrease in observed fouling phenomenon as expected.[1] Outstanding fouling was observed for $500 \mathrm{kDa}$ membrane, when $1 \mathrm{~m} \mathrm{~s}^{-1}$ CFV was applied.

Figures 6 and 7 show the evolution of normalized flux for both membranes at lower initial fluxes. Tests were conducted during $30 \mathrm{~min}$, at temperature $20^{\circ} \mathrm{C}$. For $500 \mathrm{kDa}$ tests, TMP was 0.19 bar, initial flux was $40 \mathrm{~L} \mathrm{~m}^{-2} \mathrm{~h}^{-1}$ and the tested CFVs were 1, 2, 3 and $4 \mathrm{~m} \mathrm{~s}^{-1}$; and for $1 \mathrm{kDa}$ membrane initial flux was $15 \mathrm{~L} \mathrm{~m}^{-2} \mathrm{~h}^{-1}$, TMP was 0.90 bar and the tested CFVs were 1,2 and $3 \mathrm{~m} \mathrm{~s}^{-1}$.

As could be observed by comparing Figures 5-7, lower initial fluxes caused general slowdown of the fouling process regardless of the applied CFV. Assuredly, intensity of cross-flow had the same impact as observed at a higher initial flux. It is worth noting that the normalized flux decrease for $1 \mathrm{kDa}$ membrane was within 2.33.5\% depending on applied CFVs.
Fouling tendency of ceramic membrane could be controlled by either CFV, adequate MWCO and by limiting operational flux.[1,2,19]

In addition to separate autonomous use of 500 and 1 $\mathrm{kDa}$ membranes, this research includes the use of membranes in a series mode. This means that the $500 \mathrm{kDa}$ membrane was employed as the pretreatment step to the $1 \mathrm{kDa}$ membrane separation. Table 3 gives the normalized flux decrease at the beginning and end of the separation cycle of $1 \mathrm{kDa}$ membrane separating raw mercerization wastewater and $500 \mathrm{kDa}$ permeate at $20^{\circ} \mathrm{C}$ and CFV of $3 \mathrm{~m} \mathrm{~s}^{-1}$.

Although using $500 \mathrm{kDa}$ membrane permeate slightly reduces fouling intensity on $1 \mathrm{kDa}$ membrane, it is hard to expect that this gain could justify the additional filtration step as a pretreatment.

The influence of CFV as an operating condition on TSS removal is presented in Figure 8.

Although insignificant, some influence of CFV on TSS rejection is noticeable, at least for 1 and $500 \mathrm{kDa}$ membranes. Intensified cross-flow reduces TSS rejection for $1 \mathrm{kDa}$, whilst it increases TSS rejection for $500 \mathrm{kDa}$ membrane. In both cases the change is not very important.

\subsection{Effect of temperature}

The influence of temperature on the normalized flux at the same initial flow rate and CFV was investigated for both membranes at $20^{\circ} \mathrm{C}$ and $50^{\circ} \mathrm{C}$. Prior to the separation experiments, the initial membrane and 


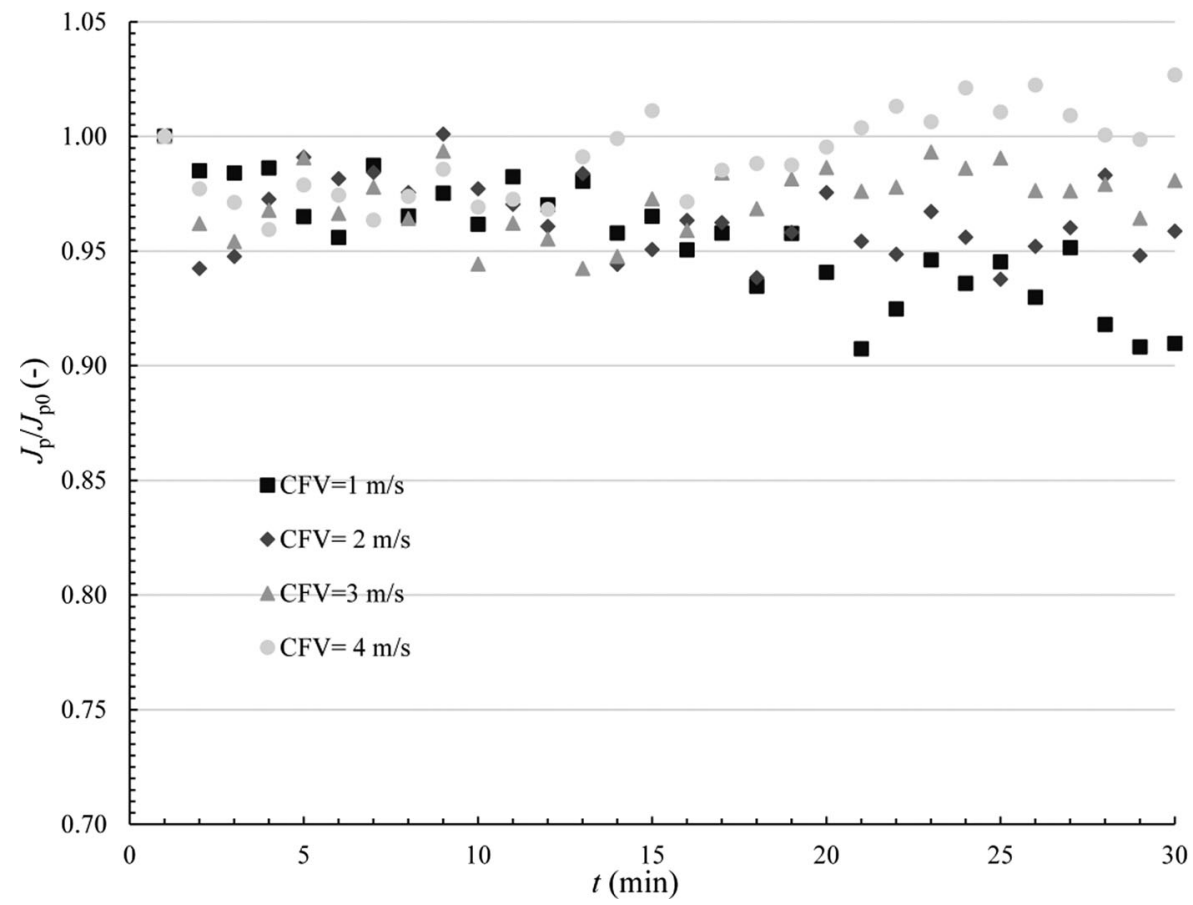

Figure 6. Effect of CFV on normalized permeate flux $\left(J_{\mathrm{P}} / J_{\mathrm{P}}\right)$ for $500 \mathrm{kDa}$ ceramic membrane at the initial flux of $40 \mathrm{~L} \mathrm{~m}^{-2} \mathrm{~h}^{-1}$.

mercerization wastewater normalized fluxes were determined by recording the permeate flux versus TMP diagram for selected temperatures. The $1 \mathrm{kDa}$ membrane normalized flux of the mercerization wastewater was $20.07 \mathrm{~L} \mathrm{~m}^{-2} \mathrm{~h}^{-1} \mathrm{bar}^{-1}\left(R^{2}=0.9997\right)$ at $20^{\circ} \mathrm{C}$ and $28.05 \mathrm{~L} \mathrm{~m}^{-2} \mathrm{~h}^{-1} \mathrm{bar}^{-1}\left(R^{2}=0.9751\right)$ at $50^{\circ} \mathrm{C}$; and for $500 \mathrm{kDa}$ it was $261.73 \mathrm{~L} \mathrm{~m}^{-2} \mathrm{~h}^{-1} \mathrm{bar}^{-1}\left(R^{2}=0.9966\right)$ at $20^{\circ} \mathrm{C}$ and $536.01 \mathrm{~L} \mathrm{~m}^{-2} \mathrm{~h}^{-1} \operatorname{bar}^{-1}\left(R^{2}=0.9981\right)$ at $50^{\circ} \mathrm{C}$. The initial flux of $500 \mathrm{kDa}$ membrane was $100 \mathrm{~L} \mathrm{~m}^{-2}$ $\mathrm{h}^{-1}, \mathrm{CFV} 4 \mathrm{~m} \mathrm{~s}^{-1}$ and initial TMP was 0.4 bar and 0.31 bar at temperatures $20^{\circ} \mathrm{C}$ and $50^{\circ} \mathrm{C}$, respectively.

For the case of $1 \mathrm{kDa}$ membrane, the initial flux was $30 \mathrm{~L} \mathrm{~m}^{-2} \mathrm{~h}^{-1}, \mathrm{CFV} 3 \mathrm{~m} \mathrm{~s}^{-1}$ and initial TMP 1.6 bar and 1.15 bar at temperatures $20^{\circ} \mathrm{C}$ and $50^{\circ} \mathrm{C}$, respectively.

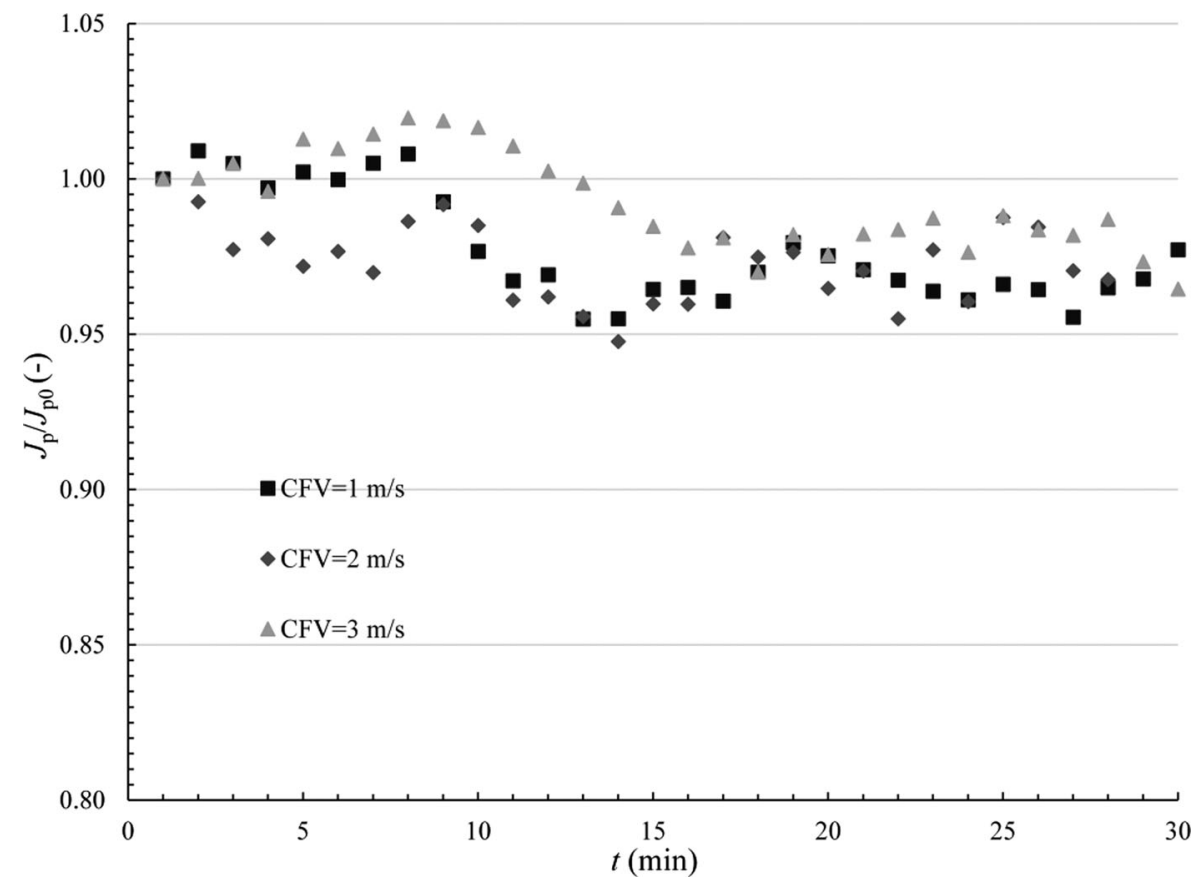

Figure 7. Effect of CFV on normalized permeate flux $\left(J_{\mathrm{P}} / J_{\mathrm{PO}}\right)$ for $1 \mathrm{kDa}$ membrane for lower initial flux of $15 \mathrm{~L} \mathrm{~m}^{-2} \mathrm{~h}^{-1}$. 
Table 3. Permeate flux at the beginning and end and the normalized permeate flux decline during raw mercerization wastewater and $500 \mathrm{kDa}$ permeate UF with $1 \mathrm{kDa}$ membrane at $20^{\circ} \mathrm{C}$ and $\mathrm{CFV}$ of $3 \mathrm{~m} \mathrm{~s}^{-1}$.

\begin{tabular}{lcc}
\hline & $\begin{array}{c}\text { Raw mercerization } \\
\text { wastewater }\end{array}$ & $\begin{array}{c}500 \text { kDa membrane } \\
\text { permeate }\end{array}$ \\
\hline $\begin{array}{l}\text { Permeate flux at the } \\
\text { beginning of the test, } \mathrm{L} \mathrm{h}^{-1}\end{array}$ & 29.01 & 29.22 \\
$\mathrm{~m}^{-2}$ & & \\
$\begin{array}{l}\text { Permeate flux at the end of } \\
\text { the test, } \mathrm{L}^{-1} \mathrm{~m}^{-2}\end{array}$ & 28.67 & 28.28 \\
$\begin{array}{l}\text { Normalized permeate flux } \\
\text { decline }\end{array}$ & $4.16 \%$ & $2.06 \%$ \\
\hline
\end{tabular}

The evolution of the normalized flux for both membranes is represented in Figure 9.

Increase in temperature caused a slight acceleration of the fouling process for both membranes. This phenomenon is most probably the consequence of viscosity drop due to temperature change and as a result of better diffusion of particles into the membrane pores.[20] Additionally, reduced viscosity will lessen drag force and the capability to detach adsorbed particles.

Besides fouling of membranes, it is interesting to observe the effect of temperature on the rejection values of relevant parameters for both membranes. In Table 1 water quality of permeate at both temperatures is given. It could be observed that an increase in temperature generally slightly reduces the rejection of TSS, TOC and color. This decline in rejection is within range of $0.5-3 \%$.

\subsection{Flux recovery}

Since membrane fouling is considered to be the main constraint for widespread membrane use, this paper includes a detailed study of flux recovery. Table 4 gives the operational data explaining fouling progress and removal for each CFV at different operational load cases during the tests.

Every presented separation test was organized in the same way, starting with a check of normalized flux with DW at a specific CFV for three different TMPs. All separation tests lasted $30 \mathrm{~min}$ and were conducted with controlled operating conditions. At the end of each run, the membrane was flushed with DW for $18 \mathrm{~s}$ at tangential velocity of $3 \mathrm{~m} \mathrm{~s}^{-1}$. Prior to further chemical cleaning, the normalized flux was measured with DW to determine chemically reversible fouling.[10] The CIP procedure was determined according to the literature [17,21-24] and some preliminary trial-and-error tests with different chemical agents, concentrations and temperatures. After the CIP process, normalized flux with DW was observed again and any remaining membrane blockage was considered as chemically irreversible fouling. It could be explained by the residual or permanent fouling formed on the fresh membrane surface through strong adsorption and inter-bonding of the attached macromolecules which prevent the cleaning mechanism from being effective. The layer of adsorbed molecules may have also undergone conformational changes, resulting in a tighter structured layer which could withstand chemical cleaning.[21] $\mathrm{HNO}_{3}$ was not used for chemical

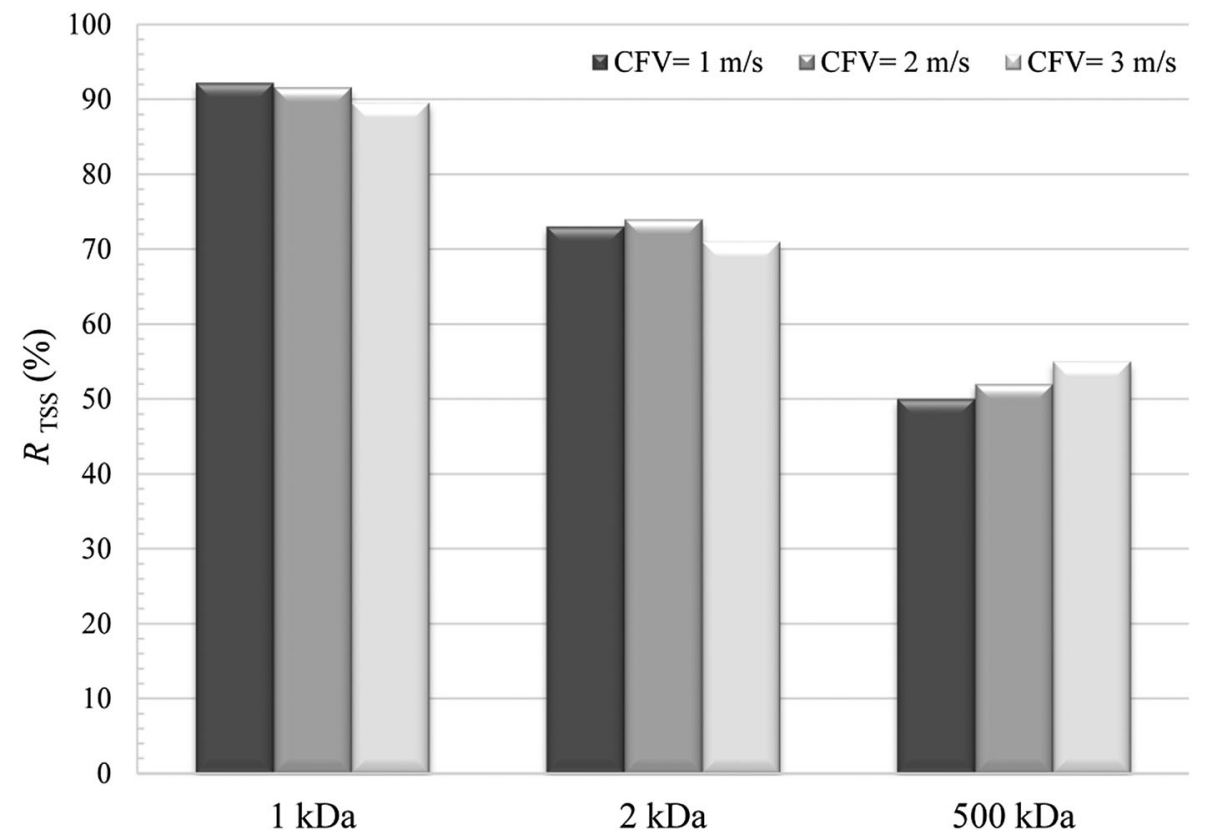

Figure 8. Influence of CFV on TSS rejection efficiency for tested 1, 2 and 500 kDa membranes. 


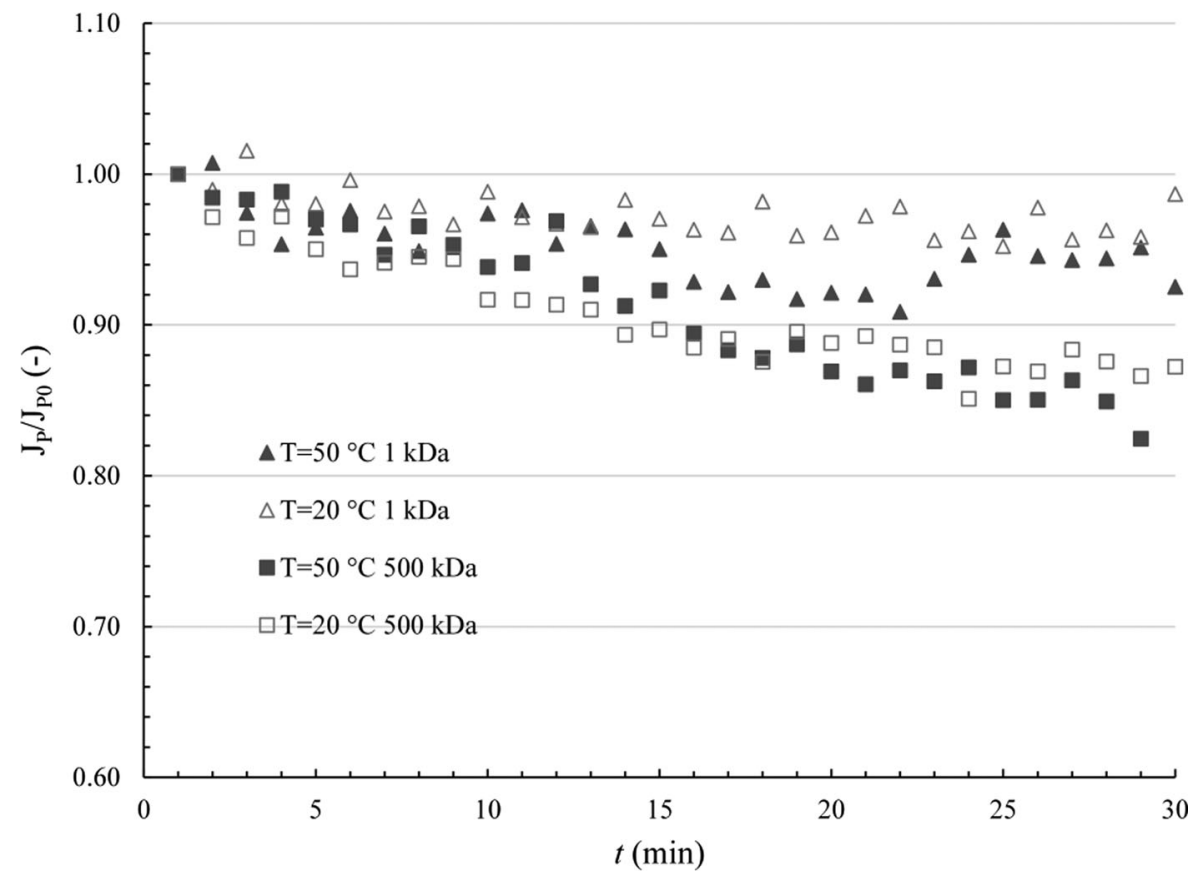

Figure 9. The influence of temperature on normalized permeate flux $\left(J_{\mathrm{p}} / J_{\mathrm{P} 0}\right)$ with temperature viscosity correction during the UF of mercerization wastewater using 1 and $500 \mathrm{kDa}$ membranes at $3 \mathrm{~m} \mathrm{~s}^{-1} \mathrm{CFV}$ and temperature of $20^{\circ} \mathrm{C}$ and $50^{\circ} \mathrm{C}$.

Table 4. Flux recovery for 1 and $500 \mathrm{kDa}$ membranes at different CFVs and high and low initial permeate fluxes, $T=20^{\circ} \mathrm{C}$.

\begin{tabular}{|c|c|c|c|c|c|}
\hline \multirow{4}{*}{$\begin{array}{l}\text { CFV, } \mathrm{m} \mathrm{s}^{-1} \\
1\end{array}$} & \multirow{3}{*}{$\begin{array}{c}\text { Membrane } \\
\text { Initial flux mercerization wastewater, } \mathrm{L} \mathrm{m}^{-2} \mathrm{~h}^{-1}\end{array}$} & \multicolumn{2}{|c|}{$1 \mathrm{kDa}$} & \multicolumn{2}{|c|}{$500 \mathrm{kDa}$} \\
\hline & & 15 & 30 & 40 & 100 \\
\hline & & \multicolumn{2}{|c|}{42} & \multicolumn{2}{|c|}{432} \\
\hline & DW normalized flux before test, $\mathrm{L} \mathrm{m}^{-2} \mathrm{~h}^{-1} \mathrm{bar}^{-1}$ & 36.6 & 39.6 & 324.3 & 340.3 \\
\hline & Mercerization wastewater normalized flux, start of test, $\mathrm{L} \mathrm{m}^{-2} \mathrm{~h}^{-1} \mathrm{bar}^{-1}$ & 17.8 & 15.9 & 322.7 & 216.4 \\
\hline & Mercerization wastewater normalized flux, end of test, $\mathrm{L} \mathrm{m}^{-2} \mathrm{~h}^{-1} \mathrm{bar}^{-1}$ & 17.4 & 14.4 & 310.6 & 112.7 \\
\hline & DW normalized flux, after test, $\mathrm{L} \mathrm{m}^{-2} \mathrm{~h}^{-1} \mathrm{bar}^{-1}$ & 29.9 & 28.5 & 307.8 & 243.7 \\
\hline & DW normalized flux, after CIP, $\mathrm{L} \mathrm{m}^{-2} \mathrm{~h}^{-1} \mathrm{bar}^{-1}$ & 33.3 & 34.6 & 340.3 & 380.7 \\
\hline \multirow{7}{*}{2} & Flux recovery, \% & 91.0 & 87.4 & $>100.0$ & $>100.0$ \\
\hline & DW normalized flux, before test, $\mathrm{L} \mathrm{m}^{-2} \mathrm{~h}^{-1} \mathrm{bar}^{-1}$ & 38.6 & 40.0 & 350.3 & 346.7 \\
\hline & Mercerization wastewater normalized flux, start of test, $\mathrm{L} \mathrm{m}^{-2} \mathrm{~h}^{-1} \mathrm{bar}^{-1}$ & 17.6 & 17.1 & 329.1 & 279.4 \\
\hline & Mercerization wastewater normalized flux, end of test, $\mathrm{L} \mathrm{m}^{-2} \mathrm{~h}^{-1} \mathrm{bar}^{-1}$ & 17.0 & 16.4 & 308.5 & 232.3 \\
\hline & DW normalized flux, after test, $\mathrm{L} \mathrm{m}^{-2} \mathrm{~h}^{-1} \mathrm{bar}^{-1}$ & 26.0 & 30.4 & 305.7 & 284.0 \\
\hline & DW normalized flux, after CIP, $\mathrm{L} \mathrm{m}^{-2} \mathrm{~h}^{-1} \mathrm{bar}^{-1}$ & 36.5 & 33.7 & 346.7 & 319.6 \\
\hline & Flux recovery, \% & 94.6 & 84.3 & $>100 \%$ & 92.2 \\
\hline \multirow[t]{6}{*}{3} & DW normalized flux, before test, $\mathrm{L} \mathrm{m}^{-2} \mathrm{~h}^{-1} \mathrm{bar}^{-1}$ & 41.7 & 42.3 & 381.4 & 367.0 \\
\hline & Mercerization wastewater normalized flux, start of test, $\mathrm{L} \mathrm{m}^{-2} \mathrm{~h}^{-1} \mathrm{bar}^{-1}$ & 16.7 & 17.8 & 246.9 & 187.9 \\
\hline & Mercerization wastewater normalized flux, end of test, $\mathrm{L} \mathrm{m}^{-2} \mathrm{~h}^{-1} \mathrm{bar}^{-1}$ & 16.1 & 17.1 & 242.2 & 168.2 \\
\hline & DW normalized flux, after test, $\mathrm{L} \mathrm{m}^{-2} \mathrm{~h}^{-1} \mathrm{bar}^{-1}$ & 29.3 & 30.7 & 275.0 & 323.1 \\
\hline & DW normalized flux, after CIP, $\mathrm{L} \mathrm{m}^{-2} \mathrm{~h}^{-1} \mathrm{bar}^{-1}$ & 35.9 & 35.8 & 315.9 & 350.3 \\
\hline & Flux recovery, \% & 86.1 & 84.6 & 81.8 & 95.4 \\
\hline \multirow[t]{6}{*}{4} & DW normalized flux, before test, $\mathrm{L} \mathrm{m}^{-2} \mathrm{~h}^{-1} \mathrm{bar}^{-1}$ & & & 432.4 & 443.5 \\
\hline & Mercerization wastewater normalized flux, start of test, $\mathrm{L} \mathrm{m}^{-2} \mathrm{~h}^{-1} \mathrm{bar}^{-1}$ & & & 233.9 & 278.9 \\
\hline & Mercerization wastewater normalized flux, end of test, $\mathrm{L} \mathrm{m}^{-2} \mathrm{~h}^{-1} \mathrm{bar}^{-1}$ & & & 240.2 & 243.2 \\
\hline & DW normalized flux, after test, $\mathrm{L} \mathrm{m}^{-2} \mathrm{~h}^{-1} \mathrm{bar}^{-1}$ & & & 381.38 & 314.1 \\
\hline & DW normalized flux, after CIP, $\mathrm{L} \mathrm{m}^{-2} \mathrm{~h}^{-1} \mathrm{bar}^{-1}$ & & & 381.4 & 367.0 \\
\hline & Flux recovery, \% & & & $88.2 \%$ & 82.8 \\
\hline
\end{tabular}

cleaning because its use caused negative flux recovery $(-33 \%)$. Some preliminary tests were conducted that involve the neutralization of mercerization wastewater, and the appearance of cellulose fibers was noticed. Raw wastewater contains dissolved cellulose fibers which are soluble in high alkaline solutions.[18] This could be the reason for the aforementioned negative flux decline recovery after acidic cleaning, and further investigation should be conducted.

Since these experiments were done with brand new membranes, buildup of chemically irreversible fouling occurred, which is obvious especially for $500 \mathrm{kDa}$ 
Table 5. Flux recovery efficiency for 1 and $500 \mathrm{kDa}$ membranes at 20 and $50^{\circ} \mathrm{C}$.

\begin{tabular}{|c|c|c|c|c|c|}
\hline \multirow{3}{*}{$\begin{array}{l}\text { Membrane and CFV } \\
\text { Inlet water } \\
\text { Temperature, }{ }^{\circ} \mathrm{C}\end{array}$} & \multicolumn{3}{|c|}{$1 \mathrm{kDa} 3 \mathrm{~m} \mathrm{~s}^{-1}$} & \multirow{2}{*}{\multicolumn{2}{|c|}{$\begin{array}{c}500 \mathrm{kDa} 4 \mathrm{~m} \mathrm{~s}^{-1} \\
\text { Mercerization } \\
\text { wastewater }\end{array}$}} \\
\hline & \multicolumn{2}{|c|}{$\begin{array}{c}\text { Mercerization } \\
\text { wastewater }\end{array}$} & 500 kDa permeate & & \\
\hline & 20 & 50 & 20 & 20 & 50 \\
\hline Initial flux mercerization wastewater, $\mathrm{L} \mathrm{m}^{-2} \mathrm{~h}^{-1}$ & \multicolumn{3}{|c|}{30} & \multicolumn{2}{|c|}{100} \\
\hline New membrane permeability to DW, $\mathrm{L} \mathrm{m}^{-2} \mathrm{~h}^{-1}$ bar $^{-1}$ & \multicolumn{3}{|c|}{42} & \multicolumn{2}{|c|}{432} \\
\hline DW normalized flux, before test, $\mathrm{L} \mathrm{m}^{-2} \mathrm{~h}^{-1}$ bar $^{-1}$ & 36.6 & 56.3 & 38.4 & 443.5 & 536.0 \\
\hline Mercerization wastewater normalized flux, start of test, $\mathrm{L} \mathrm{m}^{-2} \mathrm{~h}^{-1}$ bar $^{-1}$ & 17.8 & 27.2 & 21.3 & 310.4 & 278.9 \\
\hline Mercerization wastewater normalized flux, end of test, $\mathrm{L} \mathrm{m}^{-2} \mathrm{~h}^{-1}$ bar $^{-1}$ & 17.1 & 26.0 & 20.9 & 254.9 & 243.2 \\
\hline DW normalized flux, after test, $\mathrm{L} \mathrm{m}^{-2} \mathrm{~h}^{-1}$ bar $^{-1}$ & 29.9 & 37.6 & 32.7 & 314.1 & 428.6 \\
\hline DW normalized flux, after CIP, $\mathrm{L} \mathrm{m}^{-2} \mathrm{~h}^{-1}$ bar $^{-1}$ & 33.3 & 55.8 & 40.97 & 367.0 & 527.5 \\
\hline Flux recovery, \% & 91.0 & 99.1 & $>100.0$ & 82.8 & 98.4 \\
\hline
\end{tabular}

Table 6. Energy consumption during tangential UF and energy consumption increase during the cycle for mercerization wastewater using $500 \mathrm{kDa}$ ceramic membrane at different CFVs $\left(T=20^{\circ} \mathrm{C}\right)$.

\begin{tabular}{lcccc}
\hline CFV, $\mathrm{m} \mathrm{s}^{-1}$ & 1 & 2 & 3 & 4 \\
\hline $\begin{array}{l}\text { Energy consumption at high initial } \\
\quad \text { lux, } \mathrm{kW} \mathrm{h} \mathrm{m}^{-3}\end{array}$ & 0.171 & 1.140 & 3.780 & 7.534 \\
$\begin{array}{c}\text { Energy consumption at low initial } \\
\quad \text { flux, } \mathrm{kW} \mathrm{h} \mathrm{m}^{-3}\end{array}$ & 0.372 & 2.630 & 8.036 & 19.326 \\
$\begin{array}{l}\text { Energy consumption increase at } \\
\text { higher initial permeate flux }\end{array}$ & $46.11 \%$ & $18.54 \%$ & $7.52 \%$ & $9.30 \%$ \\
$\begin{array}{l}\text { Energy consumption increase at } \\
\text { lower initial permeate flux }\end{array}$ & $9.11 \%$ & $1.23 \%$ & $2.17 \%$ & $0.00 \%$ \\
\hline
\end{tabular}

membrane. After four sets of experiments, even intensive chemical cleaning could only achieve $74-78 \%$ of new membrane DW normalized flux.

Among the washing trials, chemically enhanced backwash was tested and appeared to be unsuccessful, causing further decline of normalized flux. An effective cleaning strategy and pore cleaning mechanism are essential to maintain the initial flux values for $500 \mathrm{kDa}$ membrane. Although caustic cleaning with $\mathrm{NaOH}$ solution is the most important cleaning agent, complete flux recovery could not be achieved without $\mathrm{NaOCl}$ and $\mathrm{H}_{2} \mathrm{O}_{2}$ solutions.

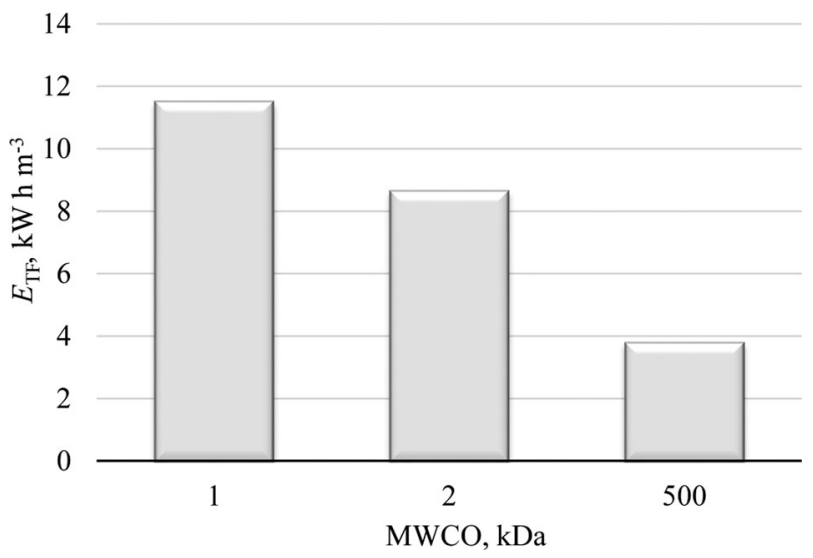

Figure 10. Energy consumption during tangential UF $\left(E_{\mathrm{TF}}\right)$ of mercerization wastewater using 1, 2 and $500 \mathrm{kDa}$ ceramic membranes at $3 \mathrm{~m} \mathrm{~s}^{-1} \mathrm{CFV}$ and $T=20^{\circ} \mathrm{C}$.
Once chemically irreversible fouling formed, the CIP procedure could accomplish 100\% flux recovery.

The $1 \mathrm{kDa}$ membrane had lower irreversible fouling intensity effect and CIP was able to recover $87 \%$ of brand new normalized flux. This could be the consequence of the different adsorption and desorption mechanisms of the foulants based on different chemical compositions of the membrane active layer.[17]

Table 5 represents the influence of temperature on fouling formation and removal for both membranes. It is obvious that the recovery of membrane flux was more effective at higher temperatures; therefore, temperature is an important operational tool when adopting a CIP strategy.

\subsection{Energy consumption}

For the purpose of energy consumption calculations, tangential flow UF tests using the $500 \mathrm{kDa}$ ceramic membrane were conducted at different CFVs: 1, 2, 3 and 4 $\mathrm{m} \mathrm{s}^{-1}$ at $20^{\circ} \mathrm{C}$ and the initial permeate flux of $100 \mathrm{~L}$ $\mathrm{m}^{-2} \mathrm{~h}^{-1}$. Test results are presented in Table 6 .

As expected, the CFV affects energy consumption directly. At high initial permeate flux for the lowest CFV of $1 \mathrm{~m}^{-\mathrm{s}}$, it was $0.171 \mathrm{kWh} \mathrm{m}^{-3}$, while for 2,3 and $4 \mathrm{~m}$ $\mathrm{s}^{-1}$ it was 7, 22 and 44 times higher. When UF was conducted at a lower initial permeate flux, energy consumption per cubic meter of produced permeate was twice as higher for all tested CFVs. Energy consumption increase due the UF cycle was more intense at lower initial flux and for lower CFVs.

In the case of membrane MWCO, energy consumption for 1,2 and $500 \mathrm{kDa}$ membranes was $11.50,8.64$ and 3.78 $\mathrm{kW}$ h per cubic meter of produced permeate, respectively, for the CFV of $3 \mathrm{~m} \mathrm{~s}^{-1}$ and $20^{\circ} \mathrm{C}$, as represented in Figure 10. Based on the obtained results, energy consumption increased for the higher membrane MWCO.

\section{Conclusions}

UF with $1 \mathrm{kDa}$ ceramic membrane could be successfully applied for mercerization wastewater treatment as 
significant removal of TSS (91.9\%), turbidity (98.15\%) and color $(98.05 \%)$ could be achieved.

It was found that lower MWCO membrane is less prone to fouling and less demanding for chemical cleaning needed to keep the performance satisfactory.

CFV appeared to be a strong tool to control fouling, whilst it had only a slight influence on the removal efficiencies.

Also, $500 \mathrm{kDa}$ membranes seem not to be suitable for the mercerization wastewater pretreatment because of its highly expressed fouling and low TSS (54.4\%) and TOC (20.2\%) removal efficiency.

Energy consumption increases due to the UF cycle, but it could be controlled either by the CFV or by limiting the operational flux. Energy consumption also increases for the membranes with higher MWCO.

Since fouling of the ceramic membrane during mercerization wastewater treatment is unavoidable, the CIP procedure is crucial in order to achieve cost-effective separation.

Results represented in this study aim at defining an optimized treatment of mercerization wastewater that will finally allow the reclamation and reuse of sodium hydroxide and auxiliary chemicals (surfactants) in the textile industry.

\section{List of abbreviations}

$\begin{array}{ll}\text { MWCO molecular weight cut-off, Da } \\ \text { CFV } & \text { cross-flow velocity } \\ \text { UF } & \text { ultrafiltration } \\ \text { TOC } & \text { total organic carbon, } \mathrm{mg} \mathrm{L}^{-1} \mathrm{C} \\ \text { TSS } & \text { total suspended solids, } \mathrm{mg} \mathrm{L}^{-1} \\ \text { TDS } & \text { total dissolved solids, } \mathrm{mg} \mathrm{L}^{-1} \\ \text { CIP } & \text { clean in place } \\ \text { TMP } & \text { transmembrane pressure }\end{array}$

\section{Disclosure statement}

No potential conflict of interest was reported by the authors.

\section{Funding information}

This work was supported by the University of Zagreb through project TP063 "Removal of specific contaminants from water using membrane processes".

\section{References}

[1] Barredo-Damas S, Alcaina-Miranda MI, Iborra-Clar MI, Mendoza-Roca J. Application of tubular ceramic ultrafiltration membranes for the treatment of integrated textile wastewaters. Chem Eng J. 2012;192:211-218.

[2] Fersi C, Gzara L, Dhahbi M. Flux decline study for textile wastewater treatment by membrane process. Desalination. 2009;244:321-332.
[3] Choo K-H, Choi S-J, Hwang E-D. Effect of coagulant types on textile wastewater reclamation in a combined coagulation/ultrafiltration system. Desalination. 2007;202:262270.

[4] Lee B-B, Choo K-H, Chang D, Choi S-J. Optimizing the coagulant dose to control membrane fouling in combined coagulation/ultrafiltration systems for textile wastewater reclamation. Chem Eng J. 2009;155:101-107.

[5] Lu X, Liu L, Liu R, Chen J. Textile wastewater reuse as an alternative water source for dyeing and finishing processes: a case study. Desalination. 2010;258:229-232.

[6] Alventosa-deLara E, Barredo-Damas S, Zuriaga-Agustí E, Alcaina-Miranda MI, Iborra-Clar MI. Ultrafiltration ceramic membrane performance during the treatment of model solutions containing dye and salt. Sep Purif Technol. 2014;129:96-105.

[7] Niren P, Jigisha P. Textile wastewater treatment using a UF hollow-fibre submerged membrane bioreactor (SMBR). Environ Technol. 2011;32:1247-1257.

[8] Yang J, Park C, Kim S. Recovery of the caustic soda in textile mercerization by combined membrane filtration. Santa Clara: NSTI-Nanoteched; 2007.

[9] Schoeberl P, Brik M, Braun R, Fuchs W. Treatment and recycling of textile wastewater - case study and development of a recycling concept. Desalination. 2004;171:173-183.

[10] Zuriaga-Agustı E, Alventosa-deLara E, Barredo-Damas S, Alcaina-Miranda Ml, Iborra-Clar MI, Mendoza-Roca JA. Performance of ceramic ultrafiltration membranes and fouling behavior of a dye-polysaccharide binary system. Water Res. 2014;54:199-210.

[11] Muthukumaran S, Baskaran K. Comparison of the performance of ceramic microfiltration and ultrafiltration membranes in the reclamation and reuse of secondary wastewater. DesalinWater Treat. 2014;52:670-677.

[12] Dizge N. Performance evaluation of cross-flow membrane system for wastewater reuse from the wood-panels industry. Environ Technol. 2014;35:681-690.

[13] Xu J, Chang C-Y, Hou J, Gao C. Comparison of approaches to minimize fouling of a UF ceramic membrane in filtration of seawater. Chem Eng J. 2013;223:722-728.

[14] Muthukumaran S, Nguyen DA, Baskaran K. Performance evaluation of different ultrafiltration membranes for the reclamation and reuse of secondary effluent. Desalination. 2011;279:383-389.

[15] Lee S-J, Dilaver M, Park P-K, Kim J-H. Comparative analysis of fouling characteristics of ceramic and polymeric microfiltration membranes using filtration models. J Membr Sci. 2013;432:97-105.

[16] Majewska-Nowak KM. Application of ceramic membranes for the separation of dye particles. Desalination. 2010;254:185-191.

[17] Chang I-S, Choo K-H, Lee $\mathrm{C}-\mathrm{H}$, et al. Application of ceramic membrane as a pretreatment in anaerobic digestion of alcohol-distillery wastes. J Membr Sci. 1994;90:131-139.

[18] Medronho B, Lindman B. Competing forces during cellulose dissolution: from solvents to mechanisms. Curr Opin Colloid Interface Sci. 2014;19:32-40.

[19] Barredo-Damas S, Alcaina-Miranda MI, Bes-Piá A, IborraClar Ml, Iborra-Clar A, Mendoza-Roca JA. Ceramic membrane behavior in textile wastewater ultrafiltration. Desalination. 2010;250:623-628. 
[20] Salahi A, Abbasi M, Mohammadi T. Permeate flux decline during UF of oily wastewater: experimental and modeling. Desalination. 2010;251:153-160.

[21] Gan Q, Howell JA, Field RW, England R, Bird MR, McKechinie MT. Synergetic cleaning procedure for a ceramic membrane fouled by beer microfiltration. J Membr Sci. 1999;155:277-289.

[22] Hofs B, Ogier J, Vries D, Beerendonk EF, Cornelissen ER. Comparison of ceramic and polymeric membrane permeability and fouling using surface water. Sep Purif Technol. 2011;79:365-374.

[23] Pérez-Gálvez R, Guadix EM, Bergé J-P, Guadix A. Operation and cleaning of ceramic membranes for the filtration of fish press liquor. J Membr Sci. 2011;384: 142-148.

[24] Tomaszewska M, Białończyk L. The chemical cleaning of ceramic membrane used in UF. Pol J Chem Technol. 2012;14:105-109. 